\title{
The position of the judge in Poland within the judicial system
}

Keywords: the judiciary, Constitution of the Republic of Poland, courts, judges, independence, National Council of the Judiciary

\begin{abstract}
The purpose of the article is to present the fundamental rules and regulations constituting the position of the judge in Poland, which finds its basis first of all in the regulations of the basic law interpreted over the years by the Constitutional Court, but now - in the norms of international law. Moreover, the author included his thoughts on the issues of the legitimization of judicial power and its relationship with the legislative and the executive. He also referred to the ongoing discussions on the status of the National Council of the Judiciary as a constitutionally-established body, whose task is to guarantee the independence of courts and the independence of judges in Poland. Furthermore, the article discusses the procedure and criteria of appointing a candidate to the position of a judge to different levels of the judiciary. It also deals with the basic elements guaranteeing the effectiveness of the principles of the independence of the judiciary such as neutrality, irremovability, incompatibility, immunity and the judge's material status.
\end{abstract}

* ORCID ID: https://orcid.org/0000-0001-7083-7840, PhD, assistant professor at the Department of Political Systems of the Faculty of Political Science and International Studies of the University of Warsaw; email: m.mistygacz@uw.edu.pl 


\section{Introductory remarks. The legitimization of judicial power}

In accordance with art. 10 of the Constitution of the Republic of Poland from 2 April, 1997', the system of government of the Republic of Poland is based on the separation of and balance between the legislative (vested in the Sejm and the Senate), the executive (vested in the President of the Republic of Poland and the Council of Minister) and the judicial (vested in courts and tribunals) powers. From a functional point of view is better, each of the enumerated powers is legitimized to exercise its power independently and they are complementary towards each other ${ }^{2}$. The principle of the separation of powers is then an indicator of, "the identity of constitutionalism, both due to its importance for the affirmation and guarantee of human rights, and its role in the sphere of the formation of the structure and rules of the functioning of a democratic state" ${ }^{3}$. Nevertheless, a reservation should be made that the additionally introduced requirement consisting of mutual balancing at the same time causes the dynamization of interactions occurring between the institutions acting within those three co-existing powers. The very division or separation of powers which remain in balance without any constitutional stabilizing mechanisms is of no greater importance since, "the triangle always remains a triangle even with changed angles and lengths of its sides" 4 .

The principle of the separation of powers is supplemented by the principle of the independence and separation of courts and tribunals, which follows from art. 173 of the Constitution. As pointed out by Leszek Garlicki, the sense of the existence of judicial power is, "its ability to administer justice and this is not possible without maintaining a distance towards political powers" 5 . The following features are characteristic of the judiciary: a) the principle of judicial independence; b) basing the activity of judicial power on law (and not on the criteria of purposefulness or effectiveness, which are the basis of the activity of the other

1 Journal of Laws. No. 78, item 483 with amendments.

2 A. Wasilewski, Władza sqdownicza w Konstytucji Rzeczypospolitej Polskiej, «Państwo i Prawo» 1998, No. 7, p. 4.

3 R. Piotrowski, Sędziowie a władza wykonawcza. Wybrane problemy konstytucyjne, «Studia Iuridica» 2008, No. 48, p. 114.

4 E. Łętowska, Fasada i rzeczywistość: relacje między jurysdykcjami tworzacymi trzecia władzę, [in:] P. Mikuli, A. Kulig, J. Karp, G. Kuca (eds.), Ustroje. Tradycje i porównania. Księga jubileuszowa dedykowana prof. dr hab. Marianowi Grzybowskiemu w siedemdziesiąta rocznice urodzin, Warszawa 2015 , p. 735.

5 L. Garlicki, Polskie prawo konstytucyjne. Zarys wyktadu, Warszawa 2017, p. 385. 
powers, especially the executive); c) assigning judicial power the task of settling disputes that arise in the process of law application: d) basing judicial decisions on formalized procedures ${ }^{6}$.

The key problems determining the eo ipso political position of a judge include the issue of the legitimization of judicial power in the political system of contemporary Poland. Searching for the answer to the question about the legitimization formula of judicial power requires for it to be placed into the context of the political transformations which took place in Poland after 1989, one of whose major consequences, in the political dimension, was the law from 31 December 1989 on changing the Constitution of Polish People's Republic ${ }^{7}$. This introduced to the basic law the principle of a democratic state ruled by law realizing the principles of social justice, which had not only a symbolic but also profoundly axiological dimension. The 'Round Table' agreement, signed on 5 April, 1989 between the government and the democratic opposition initiated the process of political transformation, one of the effects of which was the restoring of the principle of political pluralism and - in the sphere of judicial justice - the appointment of the National Council of the Judiciary (from the motion of which the President appointed the judges) ${ }^{8}$. In the period of social and political transformation the political position of a judge was shaped in opposition to the period of real socialism. The formal closure of the period of the political provisional state took place on 2 April, 1997, when the National Assembly passed the Constitution of the Republic of Poland, which in Chapter VIII Courts and Tribunals established the frameworks of the institutions composing the system of judicial power in Poland.

The rule of a democratic state of law in Poland provided the possibility of shaping a new model of the judiciary based on the assumption that judicial power is a power separate from others, and its major features include the independence of judges and the independence of the judiciary (in the institutional dimension). However, the fate of the executive and the legislative, due to their very nature, is a closer and broader cooperation, while judicial power is separated and independent in a wider sense.

The issue of the legitimization of power, including that of the judiciary, is connected with the legitimization of the whole political system,

6 Ibidem.

7 Journal of Laws No. 75, item 444.

8 The act of 7 April 1989 on changing the Constitution of the Polish People's Republic (Journal of Laws No. 19, item 101). 
especially in a situation when - before 1989 - it was the crisis related to the de-legitimization of power which was the factor that initiated the political transformation ${ }^{9}$. Judicial power, like any other power, can be placed in the political category since - as Aleksander Ratajczak indicates the, "administration of justice by the court is of political character" 10 . Or as Andrzej Antoszewski acknowledges, "judicial power participates in the shaping and strengthening of broadly understood social order (including political order) although it does this in a special manner characteristic only of itself. In this sense it is a political power in the strictest meaning of this word, for example by establishing standards of political behaviour and safeguarding their observance"11. The role of judicial power towards the other powers is a special one because by settling disputes (administration of justice) it performs the controlling function towards the other powers, especially the executive. Indeed, an independent judicial power performing this role is a necessary premise to, "realize the principle of a democratic state ruled by law"12. This is important when the meaning of the classical division of powers undergoes a far-reaching modification, or even contestation. Ryszard Małajny points out that this division has been a legal fiction for a long time ${ }^{13}$, being replaced by the monism of the executive and the legislative powers and a new classification of power comprising of the governing power and the opposition power. Nowadays a possibility is indicated of separating a 'neutral' power based on independence from the other powers, including parliament, which promotes a more effective and more objective control. Its composition includes - apart from the courts and tribunals - the bodies performing the tasks connected with control ${ }^{14}$. In a ruling from 15 January, 2009 the

9 Cf. W. Sokół, Legitymizacja polskiego systemu politycznego przed okresem i w okresie transformacji, [in:] E. Olszewski (ed.), Tradycje i wspótczesność kultury politycznej w Polsce (1918-1990), Lublin 1991.

10 A. Ratajczak, Polityczne i prawne uwarunkowania niezależności sąów oraz niezawistości sędziów w III Rzeczypospolitej, [in:] A. Łopatka, B. Kunicka-Michalska, S. Kiewlicz (eds.), Prawo - spoteczeństwo - jednostka. Ksiega jubileuszowa dedykowana Profesorowi Leszkowi Kubickiemu, Warszawa 2003, p. 105.

11 A. Antoszewski, R. Herbut, Systemy polityczne wspótczesnej Europy, Warszawa 2006, p. 282.

12 G. Kuca, P. Mikuli, Niezależna władza sądownicza. Rozważania wokót pozycji ustrojowej sądów i trybunałów w Polsce, [in:] O. Bogunki, J. Ciapała, P. Mijal (eds.), Standardy konstytucyjne a problemy władzy sądowniczej $i$ samorzadu terytorialnego. Konferencja naukowa. Szczecin 1 października 2007 r., Szczecin 2008, p. 141.

13 R.M. Małajny, Zasada podziału władzy a system rząów parlamentarnych, «Państwo i Prawo» 2009, No. 12, pp. 17-21.

14 A. Sylwestrzak, Wtadza trzecia - „neutralna”, [in:] P. Tuleja, M. Florczak-Wątor, S. Kubas (eds.), Prawa Człowieka. Społeczeństwo obywatelskie. Państwo demokratyczne, Warszawa 2010, p. 394. 
Constitutional Tribunal ${ }^{15}$ indicated that the balancing of powers means that the powers influence each other and they mutually complement their functions through their organs. This is reflected both in the cooperation of the powers with each other and in their mutual control. At the same time, judicial power can only be exercised by courts, while the other powers cannot interfere with its work or participate in it ${ }^{16}$.

The mechanism of the legitimization of judicial power takes into consideration then the 'connection' of judicial power and the related creation of its guardians with the power of political characters, first of all with the President of the Republic of Poland (directly legitimized by universal and direct elections), the Sejm - in relation to the judges of the tribunals, as well as the National Council of the Judiciary, whose composition also includes - by virtue of law - parliament members. Thus the 'dependence' on the powers possessing direct legitimization is a reference to the process of creating a democratic mandate ${ }^{17}$. The model of the legitimization of judicial power can be viewed in three dimensions. The first one is the appointment of the judges of common, military, administrative courts and the Supreme Court of the Republic of Poland (art. 179 of the Constitution). Thus, judges obtain indirect legitimization from the hands of the President, who was directly elected. The second includes the appointment of judges from an exclusive motion of the National Council of the Judiciary, whose members are parliament members (four) and Senate members (two) who possess direct legitimization, and - who possess indirect legitimization: a representative of the President of the Republic of Poland and the Minister of Justice, which ensures the partial ${ }^{18}$ legitimization of judicial power. The third one, on the other hand, refers to the participation of citizens in the administration of justice (art. 182 of the Constitution).

15 K 45/07, OTK-A 2009, No. 1, item 3.

16 The judgment of the Constitutional Court from 19 July, 2005, K 28/04.

17 J. Jaskiernia, Problem legitymizacji władzy sadowniczej $w$ ustroju politycznym Rzeczypospolitej Polskiej, [in:] A. Szmyt (ed.), Trzecia władza. Sąy i trybunaty w Polsce. Materiaty Jubileuszowego L Ogólnopolskiego Zjazdu Katedr i Zakładów Prawa Konstytucyjnego, Gdynia, 24-26 kwietnia 2008 r., Gdańsk 2008, p. 364.

18 Ibidem, p. 365. 


\section{The systemic dimension of the independence of courts and judges}

The principle of judicial independence (following from the constitutional principle of the division and balance of powers and being a part of the principle of the right to a fair trial) is treated as one of the most important rights of an individual ${ }^{19}$. Art. 178 item 1 expressed the principle of the independence of judges according to which, "Judges, within the exercise of their office, shall be independent and subject only to the Constitution and statutes." Following Poland's access to the European Union, the subjection of judges to the Constitution and statutes needed to be extended as the regulations of European law are binding in the Republic of Poland. However, the limits by which the courts are bound by the regulations of statutes is determined by their compliance with the Constitution, as the application of statutory provisions, which are in opposition to it, would lead to the violation of the principle of constitutional legalism ${ }^{20}$.

In the case of the independence of the courts is based on the separation of the judiciary from the other powers in organizational and functional dimensions, whereas in the case of the independence of judges is based on the jurisdiction of the judge. On the one hand, on its subjection to a legal norm (of constitutional and statutory rank) and, on the other, on internal belief. The independence of judges, therefore, is not the judge's right but, "the right of the society to justice administered by judges who are not subject to any external pressure, who are free from anybody's interference in the act of the administration of justice” (Katarzyna Gonera) ${ }^{21}$. The jurisdiction of the Constitutional

19 W. Santera, Sądy powszechne i Sąd Najwyższy jako władza sadownicza, [in:] A. Szmyt (ed.), Trzecia wtadza. Sądy i trybunaty w Polsce. Materiaty Jubileuszowego L Ogólnopolskiego Zjazdu Katedr i Zakładów Prawa Konstytucyjnego, Gdynia, 24-26 kwietnia 2008 r., Gdańsk 2008, pp. $97 \mathrm{ff}$. The consequence is the situation when neither the legislative nor the executive powers can administer justice and, hence, they cannot enter those domains where judges remain independent. The final decisions on the rights and duties of individuals and legal entities in specific cases belong to the exclusive competences of the judiciary. Cf. the ruling of the Constitutional Tribunal from 19 July, 2005 (K 28/04) and from 29 November, 2005 (P 16/04).

20 A. Rakowska-Trela, Niezależność, niezawistość, swoboda a dowolność. Granice wymiaru sprawiedliwości, [in:] A. Machnikowska (ed.), Legitymizacja władzy sqdowniczej, Gdańsk 2016, p. 50.

21 K. Gonera, Niezależność i niezawistość sędziowska jako podstawa państwa prawa. Wewnętrzna (intelektualna) niezależność sędziego, [in:] T. Wardyński, M. Niziołek (eds.), Niezależność sadownictwa $i$ zawodów prawniczych jako fundamenty państwa prawa. Wyzwania wspótczesności, Warszawa 2009, p. 90. 
Tribunal includes the following among the elements constituting the independence of judges: a) impartiality towards the participants in the proceedings; b) independence towards non-judicial organs (institutions); c) independence of judges towards the authorities and other judicial organs; d) independence from the influence of political factors, especially political parties; e) the internal independence of the judge $e^{22}$. The obligation to protect the elements that constitute the independence of judges is an obligation, not only of the other organs of the state, but also the obligation of judges themselves ${ }^{23}$. In a ruling from 24 June, 1998, the Constitutional Tribunal emphasized that the violation of this obligation, "might mean betray of the principle of the independence of judges and this is equal to a very serious transgression of the fundamental principles of the functioning of the justice system" 24 .

One of the principles affecting the system of judicial power and the political position of the judge in Poland is the right to a trial established in art. 45 item 1 of the Constitution according to which, "Everyone shall have the right to a fair and public hearing of his case, without undue delay, before a competent, impartial and independent court." The right to a fair trial can be viewed in two dimensions, namely as a constitutional right and as an individual right. The right to a fair trial, in accordance with the established jurisdiction of the Constitutional Tribunal, is composed of a) the right of access to a court, which includes initiation of the procedure before the court, which is an organ characterized by independence, impartiality and autonomy; b) the right to the properly framed court procedure, in accordance with justice and openness; c) the right to have a court decision; d) the right to the proper framing of the system and position of the organs examining the case ${ }^{25}$. According to art. 45 item 1 of the Constitution, the right to a fairly framed court procedure (a fair court trial) is not subject to limitations, The next, complementary principle of the administration of justice in Poland is the principle of two instances of the proceedings, following from art. 176 item 1 of the Constitution, according to which, "Court proceedings shall have at least two stages." Therefore, the basic law requires that particular categories

22 Cf. The ruling of the Constitutional Tribunal from 24 June, 1999K 3/98, OTK ZU 1998, No. 4, item 52, and the sentence of the Constitutional Tribunal from 14 April, 1999, K 8/99. OTK ZU 1999, No. 3, item 41.

23 Z. Czeszejko-Sochacki, Prawo do sąu w świetle Konstytucji RP (Ogólna charakterystyka), «Państwo i Prawo» 1997, Nos. 11-12, pp. 99-100.

24 K 3/98, OTK ZU 1998, No. 4, item 52.

25 Cf., for example, the ruling of the Constitutional Tribunal from 24 October, 2007, Sk 7/06, OTK ZU 2007, No. 9A, item 108. 
of courts should be organized in at least two stages, or they should be connected with the Supreme Court.

In connection with the experiences of the period of the People's Republic of Poland related to the violation of the independence of the judiciary, the Constitution of the Republic of Poland quite clearly determines the status of the judge and the guarantees of judges' autonomy by limiting the arbitrariness of the regulations in the form of a law ${ }^{26}$.

Art. 175 item 1 of the Constitution formulates three principal elements of the independence of the judiciary: a) it formulates the principle of judicial sentencing; b) in a fundamental way it determines the structure of the judiciary, and in a positive way it enumerates the necessary types of courts to be created; c) it rules out what kind of courts cannot be established, namely special courts and summary proceedings (meaning the proceedings in a simplified, one-instance procedure conducted in an accelerated manner), which can be established only in times of war ${ }^{27}$. The Constitution determines a list of bodies tasked with administrating justice, which decide on the binding and final character, and this cannot be extended in the form of statutes ${ }^{28}$. The constitutionally determined frameworks of the organization of the judiciary have a direct relationship with the protection of individual rights. Common courts implement the administration of justice in all matters except those which are reserved to the competences of other courts (art. 177 of the Constitution). The legislator was left with a wide range of freedom in the sphere of the internal organization of courts, including the division of competences (subject-matter, territorial and functional jurisdiction) among the courts.

The second pillar of judicial power is the principle of judges' independence. In accordance with art. 178 item 1 of the Constitution of the Republic of Poland, in implementing the administration of justice, judges are independent and are only subject to the Constitution and statutes. Therefore, the principle of judges' independence is rudimentary from the point of view of the functioning of a democratic state rules by law, and it performs the role of the basis of the state's organization although no constitutional provision defines this concept. On the one hand, it is nec-

26 Cf. M. Jabłoński, Uwagi o ewolucji gwarancji niezawistości i niezależności sędziów i sądów powszechnych, [in:] J. Trzciński, B. Banaszak (eds.), Studia nad prawem konstytucyjnym, Wrocław 1997, pp. $119 \mathrm{ff}$.

27 Cf. L. Garlicki, Uwaga 3 do art. 175, [in:] L. Garlicki (ed.), Konstytucja Rzeczypospolitej Polskiej. Komentarz, vol. IV, Warszawa 2005, p. 2.

28 Cf. The ruling of the Constitutional Tribunal from 12 December, 2001, Sk 26/01, OTK ZU 2001, No. 8, item 258. 
essary to free judges from the effect of institutional and non-institutional factors on the judge's jurisdiction and, on the other, within the field of settling disputes the judge is dependent on the binding law, conscience and internal belief. The correlate of judges' independence should always be the judge's consciousness that while holding their office they use the guarantees of full independence not only towards the parties in the proceedings, but also towards the other powers and towards public opinion $^{29}$. The limits of judges' independence are determined by the context in which the courts and judges function ${ }^{30}$. Independence is a formula which is not subject to limitation or gradation and it boils down to the formula, "yes-yes, no-no" 31 . It is based on the logic of the binary system. Such concepts as impartiality or neutrality are in close relation to the concept of judges' independence.

In a ruling from 14 April 1999, the Constitutional Tribunal indicated that independence means that in implementing the administration of justice a judge is subject to the legal norm and their internal conviction $^{32}$. Without judges' independence one cannot speak of independent and impartial judicial power and - as a consequence - of the existence of a real guarantee of the observance of law and the freedom of an individual $^{33}$. The right to a fair trial can only be secured when the adjudicating body which was appointed to settle the matter can ensure the independence of the activity of its members. While referring to the solutions of the March Constitution, the constitutional regulation in reference to judges' independence contains three elements, namely 1) it points to the principle of judges' independence; 2) it refers judges' independence to the sphere including the judge's office; 3) it establishes the judge's dependence on the constitution and the laws.

Aleksander Mogilnicki, one of the most outstanding judges of his era, the interwar period, and who was the President of the Criminal Chamber of the Supreme Court, described a judge's characterological features by saying: "the judge who - while adjudicating - is guided not only by the law and conscience but also somebody's wishes is a parody of the judge”,

29 Cf. T.T. Koncewicz, Sędzia - Herkules, [in:] Z. Brodecki (ed.), Europa sędziów, Warszawa 2007, p. 375; A. Rakowska-Trela, Sądy i sędziowie wobec niedemokratycznych przemian, «Studia Politologiczne» 2018, Vol. 47.

30 Cf. M. Wyrzykowski [in:] G. Borkowski (ed.), Granice niezawistości sędziów i niezależności sq̨ów?, Warszawa-Toruń 2016, pp. 43-46.

31 Cf. A. Rakowska-Trela, Niezależność, niezawistość, swoboda..., pp. 41 ff.

32 K 8/99, OTK ZU 1999, No. 3, item 41.

33 L. Garlicki, Uwaga 3 do art. 178 Konstytucji, [in:] L. Garlicki (ed.), Konstytucja Rzeczypospolitej Polskiej. Komentarz, vol. IV, Warszawa 2005, pp. 1-2. 
"the judge has no right or - in a rational system - need to take into consideration somebody else's opinions and wishes; they adjudicate like their conscience and law order them" 34 . When referring to the political position of the judge, he indicated that: "And the judge's independence exists not when it is ensured on paper by laws, but when a whole system of conditions in which the judge works compose the guarantee of true independence, when the judge is placed in the general state hierarchy in such a way that they do not expect anything from the government and they fear nothing, that they can safely and without a personal risk pass judgments in the way that the law and conscience order them" 35 .

\section{The political and procedural guarantees of judges' independence}

The condition for the existence and the proper functioning of judges' independence is the establishment of guarantees, which can be divided into political guarantees and procedural guarantees.

The political guarantees of judges' independence include a) the advanced professional and ethical qualifications of a judge; b) the appointment of judges by the President of the Republic of Poland for an indefinite period of time; c) the continuity of the judge's profession, the consequence of which is irremovability from the office (with the exception of a disciplinary punishment of being recalled from office, and the non-transferability to another position without the judge's agreement (art. 180 items 1, 2 of the Constitution); d) the incompatibility of the judge's office with other professions (incompatibilitas), which means the exclusion of a possibility of holding different positions (formal incompatibility) and undertaking definite kinds of activity (material incompatibility); e) incompatibility is complemented by the principle of apoliticality, the consequence of which is a ban on belonging to political parties ${ }^{36}$ and trade unions, or running a public activity incompatible with the principles of independence of courts and independence of judges; f) judicial immunity and judges' inviolability - without the prior consent of a court a judge cannot be held criminally responsible or deprived of freedom;

34 Cf. A. Mogilnicki, Sędzia a urzędnik, «Gazeta Sądowa Warszawska», 2 March, 1931, No. 9, p. 116.

35 Ibidem, p. 117.

36 M. Zubik, Ustrojowe założenia niepołaczalności mandatu parlamentarnego, «Przegląd Sejmowy» 2008, No. 4, p. 104. 
g) an order to secure the proper material status of judges, which is the economic element of the guarantee.

The procedural guarantees judges' independence, which means those that are focused around a judge's impartiality, should include a) the principle of free appraisal of evidence; b) jurisdictional independence of the penal court; c) the principle of open proceedings; d) secrecy of session and voting; e) the institution of dissenting opinion (votum separatum); f) the immutability of the adjudicating panel; g) the participation of the wider society in implementing the administration of justice; h) the institution of the exclusion of a judge from handling a case; i) the responsibility of the State Treasury for the damage caused by exercising public power against the law; j) a mechanism of appointing a panel of judges and the subject-matter and territorial competences of the court preventing arbitrary allocation of cases.

\section{The appointment of judges}

In accordance with art. 179 of the Constitution, judges are appointed for an indefinite period by the President of the Republic upon a motion from the National Council of the Judiciary. Therefore, the system of appointing judges acquires a limited form since although the President's competence is of personal character (it does not require countersignature), the appointment takes place due to a motion of the National Council of the Judiciary, which leaves to the head of state the task of deciding about the proposed candidate ${ }^{37}$.

The National Council of the Judiciary, which according to art. 186 item 1 of the Constitution safeguards the independence of courts and judges, is a participant in the process of appointing judges. It is a, "specific, independent, supreme body of the state, with its functions connected to judicial power" 38 and placed between the three powers. On the one hand, it is a body possessing the competences characteristic of the professional self-governing body. On the other hand, the list of persons composing it $^{39}$, the competences and the way some of its members are chosen are an obstacle in classifying this organ in an unambiguous way.

37 J. Ciapała, Prezydent $w$ systemie ustrojowym Polski, Warszawa 1999, p. 304.

38 A ruling of the Constitutional Tribunal from 15 December, 1999, P 6/99, OTK ZU 1999, No. 7, item 164.

39 In accordance with art. 187 item 1 of the Constitution, the National Council of the Judiciary is composed of 1) the First President of the Supreme Court, the President of the Supreme 
The National Council of the Judiciary is, therefore a collegial body with a mixed composition. Its members, with the exception of the First President of the Supreme Court, the President of the Supreme Administrative Court, the Minister of Justice and a representative of the President, are elected for four year terms of office. The National Council of the Judiciary elects the president and two vice-presidents from among its members (art. 187 item 2 of the Constitution). The basic task of the National Council of the Judiciary is to safeguard the independence of courts and judges. This task can be realized, for example, by the possibility of initiating the proceedings on the control of constitutionality of normative acts before the Constitutional Tribunal. The competences of this body as established in the law from 12 May, 2011 on the National Council of the Judiciary 40 include, among others, examining and evaluating candidates for the office of judges of the Supreme Court and for the position of judges in common, administrative and military courts as well as in the position of assistant judges in administrative courts; submitting motions to the President of the Republic of Poland to appoint judges in the Supreme Court, common courts, administrative courts and military courts as well as to appoint assistant judges in administrative courts; passing a set of principles of professional ethics for judges and assistant judges as well as safeguarding their observance in addition to expressing opinions on the state of the staff of judges and assistant judges; examining the motions for sending a judge to retirement as well as examining retired judges' applications to return to the position of a judge.

The choice of judges itself gives rise to doubts of a constitutional nature. In accordance with art. 9a item 1 of the act on the National Council of the Judiciary, the Sejm chooses from among the judges of the Supreme Court, common courts, administrative and military courts fifteen members of the Council for four year terms of office. The National Council of the Judiciary is recognized as the organ assigned to defend judicial power and it acts to protect the underlying values that form the foundation of the activity of the organs of the system of justice. Therefore, it performs the functions of integrating and representing the bodies

Administrative Court, the Minister of Justice and a representative of the President of the Republic of Poland; 2) fifteen judges chosen from amongst the judges of the Supreme Court, common courts, administrative courts and military courts; 3) 4 members chosen by the Sejm from amongst its deputies and two members chosen by the Senate from amongst its Senators.

40 Uniform text, Journal of Laws from 2019 item 84 with amendments. 
of the system of justice on the state forum ${ }^{41}$. In its present form, the law on the National Council of the Judiciary does not include guarantees on the functioning of the National Council of the Judiciary in a way which is in agreement with the standards of the independence of courts and independence of judges following from art. 6 of the European Convention on Human Rights. In a ruling from 18 July, 2007 the Constitutional Tribunal expressed the opinion that members of the National Council of the Judiciary can be the judges elected by judges ${ }^{42}$. In a ruling from 25 March, 2019 the Constitutional Tribunal changed that opinion by confirming the possibility that the Sejm could appointing judges in the course of the election procedure ${ }^{43}$. This opinion is in opposition to the ratio legis of the organization and functioning of this body in agreement with the requirements of independence and autonomy ${ }^{44}$.

The status of the National Council of the Judiciary was referred to by the Court of Justice of the European Union in its ruling from 19 November, $2019^{45}$, directly indicating that an assessment of the degree of independence of the National Council of the Judiciary must be made in the context of independence from the legislative and executive powers. Such assessment of the body which - by virtue of art. 186 of the Constitution - safeguards the independence of courts and judges can be of importance while checking whether the judges appointed by it will be able to meet the requirements of independence and impartiality following from art. 47 of the charter of fundamental rights. The Court pointed out that all the factors, together with the circumstances in which those choices were made, when considered together, can lead to some doubts as to the independence of the body participating in the procedure of appointing

41 A. Bałaban, Krajowa Rada Sąownictwa - regulacja konstytucyjna i rola w systemie władzy sadowniczej, [in:] W. Skrzydło (ed.), Sądy i trybunały w Konstytucji i praktyce, Warszawa 2005, p. 81, and M. Niezgódka-Medek, Krajowa Rada Sądownictwa - jako gwarant niezależności sądów i niezawistości sędziów do czasu wprowadzenia zmiana na przetomie 2017 i 2018 r., [in:] Ł. Bojarski, K. Grajewski, J. Kremer, G. Ott, W. Żurek (eds.), Konstytucja. Praworzadność Wtadza sądownicza. Aktualne problemy trzeciej władzy w Polsce, Warszawa 2019, p. 103.

42 K 25/07, OTK ZU 2007, No. 7A, item 80.

43 K 12/18, OTK ZU 2019, item 17/A. However, it needs to be emphasized that the adjudicating panel included Justyn Piskorski, who at the same time performed the function of the judge rapporteur. He was unauthorized to perform the duties of a judge of the Constitutional Tribunal as he had been "elected" replacing deceased Lech Morawski, who was also elected as a result of the violation of art. 194 item 1 of the Constitution. Cf. the sentence of the Constitutional Tribunal from 3 December, 2015, K 34/15.

44 B. Naleziński, Uwaga 6 do art. 187 Konstytucji, [in:] P. Tuleja (ed.), Konstytucja Rzeczypospolitej Polskiej. Komentarz, Warszawa 2019, p. 558.

45 C-585, C-624, C-625, EU: C:2019:982, points 138-139 and 143-144. 
judges, even if such a conclusion did not come to mind when those factors were viewed separately. These factors included the circumstance that the National Council of the Judiciary in its new composition was established by way of shortening the four year terms of office of the members who had earlier composed this body. The second circumstance is that although 15 members of the National Council of the Judiciary come from the ranks of the judiciary, they were earlier chosen by other judges, now they are designated by a body of the legislative power from among the candidates who can be proposed by a group of 200 citizens or 25 judges. The consequence of the above fact is an increase in the number of the National Council of the Judiciary members that are recommended by the political forces or elected by the latter from 23 to 25 members which compose this body. Finally, according to the assessment of the Court, the occurrence of possible irregularities that might appear in the process of appointing some of the members of the National Council of the Judiciary requires verification. The Supreme Court, in its ruling from 5 December 201946, stated - after a thorough analysis - that the National Council of the Judiciary in its present composition is not an impartial body independent from the legislative and executive powers ${ }^{47}$. The assessment of the actual activity of the National Council of the Judiciary confirms that the choice of judges, who are now members of the National Council of the Judiciary, was not carried out in a transparent way, and it was burdened with doubts concerning the choice in respect of the actual support obtained by the candidates. Moreover, there is no material basis to acknowledge that the National Council of the Judiciary is really a body safeguarding the independence of courts and the independence of judges.

Judges of common courts appointed to the office to the position of a judge are called by the President of the Republic of Poland from a motion of the National Council of the Judiciary within a month since the day when the motion was sent. The President of the Republic of Poland

46 PO 7/18. Cf. http://www.sn.pl/aktualnosci/SiteAssets/Lists/Komunikaty_o_sprawach/AllItems/III-PO-0007_18.pdf (29.12.2019).

47 In the above judgment, the Supreme Court also pointed out that filling the Disciplinary Chamber of the Supreme Court with, "only new persons, whose connections with the legislative and the executive powers are strong and who, before the nomination, were beneficiaries of changes in the administration of justice and were chosen by the National Council of the Judiciary (not acting independently of the legislative and the executive, with a broad autonomy and competences taken away from other courts and other chambers of the Supreme Court), the consequence which clearly and explicitly follows is that the Disciplinary Chamber of the Supreme Court is not a court in the understanding of art. 47 of the Charter of Fundamental Rights and art. 45 item 1 of the Constitution of the Republic of Poland". 
gives legitimization of judicial power in the name of the sovereign and a solemn appointment to the office of a judge is of emblematic character. Judges of common courts are appointed to the positions of 1) a judge of the regional court; 2) a judge of the district courts; 3 ) a judge of the appellative court. The act of appointment to the office of a judge at the same time establishes the scope of judicial power granted to a judge. It includes the seat of the judge and the associated jurisdiction. The qualifications necessary to take up the position of a judge are different and they depend on the level of court where the candidate aspires.

The appointment to the post of a judge is connected with the establishment of a labour based relationship which is a special public and legal relation with a three-element form of a legal relationship. It includes the exercise of public authority, participation in judicial self-government, and employment. Thus, it's a labour based relationship with complex content and a special character. A judge's employment relationship is established at the moment the oath is taken. The employment relationship expires as a result of a judge resigning from office or reaching the maximum age allowed to hold a judge's office. At present it is 65 years of age for the judges of common courts although in exceptional cases the office can be held longer. Termination of employment also takes place if a disciplinary court dismisses a judge from office as a punishment, a criminal measure in the form of being deprived public rights or the prohibition to hold the office of a judge imposed on a judge by the adjudicating court in criminal proceedings. A judge's employment relationship also expires if a judge gives up Polish citizenship.

\section{The irremovability from office of a judge}

In accordance with art. 180 of the Constitution, judges are irremovable. The relation between the prohibition on depriving a judge of office and the principle of independence of a judge is fairly obvious. A prohibition to remove judges, which concerns the deprivation of a judge's office in an arbitrary manner, is aimed to frame the principle of professional stability. Recall of a judge from office, suspension from office, transfer to another bench or position against his will, may only occur by virtue of a court judgment and hence it refers to a specific judge. The organ exclusively competent to decide in this case is the court in the understanding of the basic law (art. 175 item 1 of the Constitution). The premises to recall a judge from office should be prescribed in statute. 
Besides, judges bear disciplinary responsibility. In accordance with art. $107 \S 1$ of the Law on the System of Common Courts ${ }^{48}$, a judge bears disciplinary liability for misconduct including obvious and serious offense against the regulations of law and affront to the dignity of the post of judge. Therefore, disciplinary responsibility is divided into two kinds of disciplinary derelictions resulting in disciplinary responsibility. The first one, namely is an obvious and serious offense against the regulations of law, refers to both the regulations of material, procedural law and the regulations of structural and organizational character. The other category of disciplinary derelictions concerns an affront to the dignity of the post of judge, and it includes behaviour, which can be included within a broad category of infra dignitatem behaviours and which comprise unethical behaviour that may cause a negative public reaction, the undermining of trust in a judge's honesty and impartiality or resulting in social repulsive feelings. The dignity of the post of the judge constitutes an attribute related to the authority of the court and a judge personally.

\section{The incompatibility and apoliticality of the office of a judge}

The organizational and functional separation of the court from other state bodies also requires personal separation, which means the principle of incompatibility (incompatibilitatis). From this perspective, incompatibility comprises of formal and material aspects. The formal aspect includes the prohibition on the combination of holding the mandate of a member of parliament with another state function or post, while in the material aspect it is a ban on undertaking or pursuing a definite activity. The aim of the institution of incompatibility is an attempt the guarantee the independence of holding an office and the elimination of corruption and conflicts of interest ${ }^{49}$. In the act from 6 February, $1996^{50}$ the Constitutional Tribunal points out that, "a ban on combining the parliamentary mandate with definite state posts is a consequence of the basic principles determining the political system of the state based on the principle of separation of powers and it is expected to serve realization of these principles, including independence of the legislative power

\footnotetext{
48 The Act from 27 July 2001 Prawo o ustroju sądów powszechnych (Journal of Laws from 2019, item 52 with amendments).

49 L. Garlicki, Uwaga 2 do art. 103 Konstytucji, [in:] L. Garlicki (ed.), Konstytucja Rzeczypospolitej Polskiej. Komentarz, vol. II, Warszawa 2001, p. 1.

50 W 11/95, OTK ZU 1996, No. 1.
} 
from the executive, independence of a judge, political neutrality of definite state services". In accordance with art. 103 of the Constitution of the Republic of Poland, no judge, public prosecutor, officer of the civil service, soldier on active military service or functionary of the police or of the services of State protection can exercise the mandate of a Deputy.

In the Act from 6 February, 1996 the Constitutional Tribunal also indicated that, "combining a state function with another activity is limited if this is necessary because of the protection of reliability of the function held or the correctness of its performance. Within the scope that the Constitution decides that performing a definite state function requires avoiding the possibility of a conflict of interests, when particular functions or activities undertaken by the same person collide with each other, it will subject the persons in state service to special limitations" 51 .

In a ruling from 17 November, 1998 the Constitutional Tribunal decided that, "an integral component of the concept of impartiality is apoliticality - meaning not a lack of political views but not manifesting them in professional work" 52 . In the assessment of the Constitutional Tribunal, "it is understandable to introduce such regulations which form more rigorous guarantees of impartiality of those organs, especially where the scope of the granted competences is so broad that it enters the sphere of other persons' rights and freedoms" 53 .

Political neutrality (apoliticality) assumes above all that the actions of public functionaries cannot to any degree be determined by their political, religious or ideological beliefs, party or group interests. Apoliticality should be understood in the sense that a functionary does not take part in the broadly understood political game and they are, therefore, free in their functioning from a specific 'complex' of any party, political option, ideology, religion, determinants or conditions. Political neutrality should be perceived not only as independence from political parties, but also as being independent from the influence of other organizations. A separation of posts of a political character, and those filled according to political criteria is supposed to serve as an assurance of political neutrality.

M. Zubik points out that the incompatibility of public posts realizes, for example, the following aims: "a) it serves the realization of the principle of the separation of powers in organizational and functional aspects; b) it provides institutional guarantees of the independence of the performance of duties by persons holding public posts; c) it coun-

51 W 11/95.

52 K 42/97 (OTK ZU 1998, No. 7, item 113).

53 K 42/97. 
teracts conflict of interests, and seeks to eliminate corruptive influences; d) it secures transparency in decision making; e) it is an element of rational management of human resources" 54 .

A judge on duty and off duty should safeguard the dignity of the office and avoid everything which could bring dishonour to the dignity of a judge or undermine trust in their impartiality (art. $82 \S 2$ of the Law on the System of Common Courts). While holding the post a judge cannot belong to a political party or take part in any political activity. Taking an active attitude to current political conflicts and the public identification with the program of a definite political party would be signs of political activity $^{55}$. At the same time if the foundations of a democratic state of law were being violated, a judges' reticence or silence should be considered to be unethical behaviour. Excessive rigor in interpreting the restrictions including voicing one's opinion could lead to a chilling effect ${ }^{56}$.

\section{A judge's immunity and inviolability}

In accordance with art. 181 of the Constitution, a judge cannot, without prior consent granted by a court specified by statute, be held criminally responsible or deprived of liberty. A judge can be neither detained nor arrested, except for cases when their detention is necessary for securing the proper course of proceedings. The president of the competent local court must be immediately notified of such detention and they may order an immediate release of the person detained. A judge's immunity has the function of securing them from chicanery or revenge. This right is conferred on judges holding the office and retired judges. The inclusion of the judges of the Constitutional Tribunal and the Tribunal of State to the protection of immunity follows from art. 196 and art 200 of the Constitution.

The 1997 Constitution regulated not only a broad constitutionalization of a judge's status but also the issue of a judge's immunity ${ }^{57}$. The basic function of immunity is the protection of the independence of

54 M. Zubik, Ustrojowe zatożenia niepołaczalności mandatu parlamentarnego, «Przegląd Sejmowy» 2008, No. 4, p. 107.

55 Cf. M. Laskowski, Uchybienie godności urzędu sędziego jako podstawa odpowiedzialności dyscyplinarnej, Warszawa 2019, p. 79.

56 Ibidem, pp. 344-345.

57 Judicial immunity was for the first time regulated in the March Constitution from 1921. In the period after World War II, judicial immunity was regulated only by statute. 
courts and guaranteeing a fair trial as well as securing the process of adjudicating. Immunity includes the time from the moment a judge is called to their post until the termination of the employment relationship, which means recall from the office, resignation or death. A judge cannot give up immunity since it protects the institution and not the judge personally.

\section{The material status of a judge}

Ensuring the dignity of the office of judge in a material dimension is connected, on the one hand, with the issue of the constitutional establishment of a judge's remuneration, which should significantly exceed the average salary for a job in the public sector. On the other hand, a judge's remuneration should be free from arbitrary determination. In a ruling from 4 October, 2000 the Constitutional Tribunal pointed to, "certain objective frameworks determining the legislator's freedom - within the constitution - of regulations in this respect. The first level of reference is the level of average remuneration in the public sector with the assumption that the level of a judge's remuneration - also in case of a judge of the regional court - should considerably exceed the average salary in the public sector. Secondly, a judge's remuneration should in the long term should grow at a rate that is not less than the growth of the average salary in the public sector. Thirdly, in case of problems in the state's budget a judge's remuneration should be especially protected from excessively negative fluctuations. Finally, a judge's remuneration should not be lowered by way of normative regulations" 58 .

What follows from this status apart from guaranteeing their material status, which is connected with the profession of a judge and their social position, are the limitations related to the possibility of obtaining extra income, which is supposed to eliminate the potential conflict of interests. A judge can take up employment only in academic, academic-teaching or teaching posts, only when it does not interfere in performing the duties of a judge. There is a close relation between the independence of a judge and the right to retirement, which is understood to be a special kind of a public law employment relationship of a judge who has closed their active professional career with the state ${ }^{59}$.

58 P 8/00, OTK ZU 2000, No. 6, item 189.

59 M. Zubik, Status prawny sędziego Trybunatu Konstytucyjnego, Warszawa 2011, p. 149. 
In accordance with art. 180 item 3 of the Constitution, a judge may be retired as a result of illness or infirmity which prevents him from discharging the duties of his office. Additionally, after the age limit determined by statue is reached by a judge, they go into retirement, which is a special institution against the background of mechanisms securing professionally inactive persons. The state of retirement should not be viewed only on the level of benefit of social character. A person who goes into retirement still keeps the status of a judge, what changes is the character of the employment relationship in which they remain ${ }^{60}$. A judge's retirement then performs the function of a guarantee. As opposed to the regulations of others professional groups, the constitutionalization of a judge's state of retirement follows from the special role of a judge in the state's system of governance. A judge who is materially independent and does not fear about their or their family's future seems to be less susceptible to external facts affecting their behaviour ${ }^{61}$.

\section{Administrative supervision}

The position of a judge is also connected with the issue of the supervision exercised over the administrative activity of common and military courts by the Minister of Justice. In accordance with art. 9 of the Law on Common Courts Organization, supervision over the activity of the courts is exercised by the Minister of Justice personally and through the competent service of supervision. In this way the legislator introduces the concept of administrative supervision in addition to judicative supervision. The administrative supervision of the Minister of Justice, including general administrative activities (management and organization activity of courts) by the legislator is set against the supervision that the Supreme Court exercises over the activity of courts in the sphere of jurisdiction. It is important that administrative supervision should not interfere with judicial independence and the independence of judges, and that it should not enter the spheres of administrative activity directly associated with the administration of justice. Certain doubts have frequently appeared whether these activities still belong to the scope of activities connected with court administration, or have

60 Cf. The decision of the Constitutional Tribunal from 23 February, 2000, Ts 118/99, OTK ZU 2000, No. 5, item 154.

61 See more in: B. Stępień-Załucka, Sędziowski stan spoczynku. Studium konstytucyjnoprawne, Warszawa 2019, pp. 81-96. 
they already stepped into the sphere of jurisdiction. This refers, for example, to the appointment of court chairmen whose competences are of a dual character, both administrative and judicative. The result of a ruling of the Constitutional Tribunal from 15 January, 2009 was to recognizing as inadmissible to combine a judge's delegation to perform functions in the Ministry of Justice with further functions of making judicial decisions ${ }^{62}$.

The principle of the independence and separation of courts is also realized in the statute on the system, which regulates the status and organization of courts, that guarantees the proper participation of judges' self-government in the process of appointing the chairman of the court, whereas the regulations granting a body of the executive power (Minister of Justice) a discretional power in the appointment of the chairmen of courts, which are bodies of judicial power, were considered as standing in contradiction to this principle ${ }^{63}$. The unlimited influence of the Minister of Justice on filling these posts by persons appointed only by a body of the executive power can result in an unjustified influence of the minister - via the judge so appointed to be the chairman - on jurisdiction. Therefore, to guarantee the independence of the courts, it is essential that the statute guarantees the proper participation of the judges' selfgovernment in the appointment of the chairman, if only in the form of a possibility for a competent organ of judicial power to give a negative opinion $^{64}$. It needs to be mentioned that the influence on the choice of the chairpersons of the Supreme Court, the Supreme Administrative Courts or the Constitutional Tribunal was granted to an assembly of judges who indicate candidates to these posts.

\section{Conclusion}

Independence and impartiality are the features of the judiciary which constitute the basis of a democratic state of law. The separation of the judiciary, an element of the principle of separation of powers, significantly limits the principle of the nation's sovereignty and representation. The principle of the supremacy of the nation is limited by human rights, whose source lies in the inviolability of man's dignity. As viewed

62 K 45/07, OTK-A 2009, No. 1, item 3.

63 Cf. B. Banaszak, Konstytucja Rzeczypospolitej Polskiej. Komentarz, Warszawa 2012, p. 872.

64 Cf. The decision of the Constitutional Tribunal from 15 January, 2009, K 45/07. 
by Ryszard Piotrowski, "values expressed in law" 65 are the sovereign. An increase in the importance of the position of courts is positively correlated, in a constitutional democracy, with the process of European integration, which is a consequence of the permeation into the legal culture of positive law, with the simultaneous limitation of minimizing the position of judges, which is a tendency characteristic of legal illuminism.

One of the dimensions of independence refers to the concept of 'collective independence', which includes the functioning of judges not only as individuals possessing independence and autonomy but also as, "a community creating, through internal interactions, additional features of power"66. Independence viewed in this way plays an integrating role, and it significantly contributes to the strengthening of the attributes of a judge's power and facilitates expression in the form and content which are understandable not only to the parties interested but also to the citizens.

The job of a judge only has any sense when it is connected with social respect and trust. Therefore, a judge's office is now considered to be one of the professions which require the formulation of professional ethics, understood as a set of rules of conduct independently of moral norms ${ }^{67}$. The words of a judge's oath, referring to conscience, point to the judge as a person burdened with the responsibility to apply the law. By applying the law, a judge seems to make it alive by interpreting the regulations in accordance with conscience. The appearance of a judge's professional ethics is connected with a limited possibility of fully controlling the activity of a judge granted with the task of the administration of justice. The role of professional ethics is to help in the bearing of that responsibility 68 . To be socially recognized, which means to get social legitimization, judges have to work not only through ratione imperii but above all through impero rationis.

65 R. Piotrowski, Zagadnienie legitymizacji wtadzy sądowniczej $w$ demokratycznym państwie prawnym, [in:] A. Machnikowska (ed.), Legitymizacja władzy sadowniczej, Gdańsk 2016, p. 12.

66 A. Machnikowska, O niezawistości sędziów i niezależności sądów w trudnych czasach. Wymiar sprawiedliwości $w$ pułapce sprawności, Warszawa 2018, p. 45.

67 T. Romer, M. Najda, Etyka dla sędziów. Rozważania, Warszawa 2007, p. 8.

68 Ibidem, p. 13. 


\section{Bibliography}

A. Antoszewski, R. Herbut, Systemy polityczne wspótczesnej Europy, Warszawa 2006.

A. Bałaban, Krajowa Rada Sadownictwa - regulacja konstytucyjna $i$ rola $w$ systemie władzy sądowniczej, [in:] W. Skrzydło (ed.), Sady i trybunały w Konstytucji i praktyce, Warszawa 2005.

J. Ciapała, Prezydent w systemie ustrojowym Polski, Warszawa 1999.

Z. Czeszejko-Sochacki, Prawo do sądu w świetle Konstytucji RP (Ogólna charakterystyka), «Państwo i Prawo»1997, No. 11-12.

L. Garlicki (ed.), Konstytucja Rzeczypospolitej Polskiej. Komentarz, vol. II, Warszawa 2001.

L. Garlicki (ed.), Konstytucja Rzeczypospolitej Polskiej. Komentarz, vol. IV, Warszawa 2005.

L. Garlicki, Polskie prawo konstytucyjne. Zarys wyktadu, Warszawa 2017.

K. Gonera, Niezależność i niezawistość sędziowska jako podstawa państwa prawa. Wewnętrzna (intelektualna) niezależność sędziego, [in:] T. Wardyński, M. Niziołek (eds.), Niezależność sądownictwa i zawodów prawniczych jako fundamenty państwa prawa. Wyzwania wspótczesności, Warszawa 2009.

M. Jabłoński, Uwagi o ewolucji gwarancji niezawisłości i niezależności sędziów i sądów powszechnych, [in:] J. Trzciński, B. Banaszak (eds.), Studia nad prawem konstytucyjnym, Wrocław 1997.

J. Jaskiernia, Problem legitymizacji władzy sadowniczej $w$ ustroju politycznym Rzeczypospolitej Polskiej, [in:] A. Szmyt (ed.), Trzecia władza. Sady i trybunaty w Polsce. Materiaty Jubileuszowego L Ogólnopolskiego Zjazdu Katedr i Zakładów Prawa Konstytucyjnego, Gdynia, 24-26 kwietnia 2008 r., Gdańsk 2008.

T.T. Koncewicz, Sędzia - Herkules, [in:] Z. Brodecki (ed.), Europa sędziów, Warszawa 2007.

G. Kuca, P. Mikuli, Niezależna władza sądownicza. Rozważania wokót pozycji ustrojowej sąów i trybunałów w Polsce, [in:] O. Bogunki, J. Ciapała, P. Mijal (eds.), Standardy konstytucyjne a problemy wtadzy sądowniczej $i$ samorzadu terytorialnego. Konferencja naukowa. Szczecin 1 października 2007 r., Szczecin 2008.

M. Laskowski, Uchybienie godności urzędu sędziego jako podstawa odpowiedzialności dyscyplinarnej, Warszawa 2019.

E. Łętowska, Fasada i rzeczywistość: relacje między jurysdykcjami tworzacymi trzecia władzę, [in:] P. Mikuli, A. Kulig, J. Karp, G. Kuca (eds.), Ustroje. Tradycje i porównania. Księga jubileuszowa dedykowana prof. dr hab. Marianowi Grzybowskiemu w siedemdziesiata rocznice urodzin, Warszawa 2015.

A. Machnikowska, O niezawistości sędziów i niezależności sądów w trudnych czasach. Wymiar sprawiedliwości $w$ putapce sprawności, Warszawa 2018.

R.M. Małajny, Zasada podziału władzy a system rzadów parlamentarnych, «Państwo i Prawo» 2009, No. 12.

B. Naleziński, Uwagi do art. 187 Konstytucji, [in:] P. Tuleja (ed.), Konstytucja Rzeczypospolitej Polskiej. Komentarz, Warszawa 2019.

M. Niezgódka-Medek, Krajowa Rada Sąownictwa - jako gwarant niezależności sądów i niezawistości sędziów do czasu wprowadzenia zmiana na przełomie 2017 i 2018 r., [in:] Ł. Bojarski, K. Grajewski, J. Kremer, G. Ott, W. Żurek (eds.), Konstytucja. Praworzadność Wtadza sadownicza. Aktualne problemy trzeciej władzy w Polsce, Warszawa 2019.

R. Piotrowski, Sędziowie a władza wykonawcza. Wybrane problemy konstytucyjne, «Studia Iuridica» 2008, No. 48.

R. Piotrowski, Zagadnienie legitymizacji władzy sadowniczej $w$ demokratycznym państwie prawnym, [in:] A. Machnikowska (ed.), Legitymizacja władzy sadowniczej, Gdańsk 2016. 
A. Rakowska-Trela, Niezależność, niezawisłość, swoboda a dowolność. Granice wymiaru sprawiedliwości, [in:] A. Machnikowska (ed.), Legitymizacja władzy sąowniczej, Gdańsk 2016.

A. Rakowska-Trela, Sądy i sędziowie wobec niedemokratycznych przemian, «Studia Politologiczne» 2018, Vol. 47.

A. Ratajczak, Polityczne i prawne uwarunkowania niezależności sądów oraz niezawisłości sędziów w III Rzeczypospolitej, [in:] A. Łopatka, B. Kunicka-Michalska, S. Kiewlicz (eds.), Prawo - społeczeństwo - jednostka. Ksiega jubileuszowa dedykowana Profesorowi Leszkowi Kubickiemu, Warszawa 2003.

T. Romer, M. Najda, Etyka dla sędziów. Rozważania, Warszawa 2007.

W. Santera, Sąy powszechne i Sąd Najwyższy jako władza sąownicza, [in:] A. Szmyt (eds.), Trzecia władza. Sądy i trybunaty w Polsce. Materiały Jubileuszowego L Ogólnopolskiego Zjazdu Katedr i Zakładów Prawa Konstytucyjnego, Gdynia, 24-26 kwietnia 2008 r., Gdańsk 2008.

W. Sokół, Legitymizacja polskiego systemu politycznego przed okresem i $w$ okresie transformacji, [in:] E. Olszewski (ed.), Tradycje i wspótczesność kultury politycznej w Polsce (1918-1990), Lublin 1991.

B. Stępień-Załucka, Sędziowski stan spoczynku. Studium konstytucyjnoprawne, Warszawa 2019.

A. Sylwestrzak, Wtadza trzecia - „neutralna”, [in:] P. Tuleja, M. Florczak-Wątor, S. Kubas (eds.), Prawa Człowieka. Społeczeństwo obywatelskie. Państwo demokratyczne, Warszawa 2010.

A. Wasilewski, Władza sądownicza w Konstytucji Rzeczypospolitej Polskiej, «Państwo i Prawo» 1998, No. 7.

M. Wyrzykowski, [in:] G. Borkowski (ed.), Granice niezawistości sędziów i niezależności sąów?, Warszawa-Torun 2016.

M. Zubik, Status prawny sędziego Trybunatu Konstytucyjnego, Warszawa 2011.

M. Zubik, Ustrojowe założenia niepołączalności mandatu parlamentarnego, «Przegląd Sejmowy» 2008, No. 4. 